\title{
Bibliometric analysis of art exhibit reviews in the Arts \& Humanities Citation Index
}

\author{
Wei-Ming Wang ${ }^{1}$ and Yuh-Shan $\mathrm{Ho}^{2}$ \\ ${ }^{1}$ Department of Digital Media Design, Asia University, \\ No. 500, Lioufeng Road, Wufeng, Taichung County 41354, TAIWAN \\ ${ }^{2}$ Trend Research Centre, Asia University, \\ No. 500, Lioufeng Road, Wufeng, Taichung County 41354, TAIWAN \\ e-mail: paintming@gmail.com; ysho@asia.edu.tw (corresponding author)
}

\begin{abstract}
Art exhibit reviews is one of document types in the Arts \& Humanities Citation Index (A\&HCI). Art exhibit reviews in A\&HCl from 1994 to 2013 were analyzed in terms of languages, publication output, authors, Web of Science categories, journals, and art exhibit reviews' title. Most of the art exhibit reviews were contributed by only one author. Authors prefer to publish their art exhibit reviews in the same journal. The editor of Magazine Antiques, A.E. Ledes, the editors of Art in America and Connaissance des Arts were high productive authors. Art was the leading subject category with a great majority of art exhibit reviews. More than a half of art exhibit reviews were published in Art in America, Artnews, Connaissance des Arts, Artforum International, and Burlington Magazine. Artists, art, new, world, modern, museum, and collection were the most frequently used in art exhibit reviews' title.
\end{abstract}

Keywords: Arts \& Humanities Citation Index; Art Exhibit Reviews; Web of Science Core Collection; Scientometrics; Galleries and Museums.

\section{INTRODUCTION}

Various document types are defined in the Web of Science Core Collection which covers the Science Citation Index Expanded (SCIE), Social Sciences Citation Index (SSCI), and Arts \& Humanities Citation Index (A\&HCl). The article document type, generally published in a journal, is focused the most in bibliometric studies such as revealed in Chiu and Ho (2007) and Ho (2013; 2014). Studies based on proceedings paper (Ingwersen et al. 2014; Sigogneau 2000; Zhang and Glanzel 2012) and review (Agudelo, Breton-Lopez and BuelaCasal 2003; Ho and Kahn 2014; Justiss 2003; Manriquez et al. 2015) as document types were also reported. These studies predominantly cover resources indexed in SCIE and SSCI databases. Although not in the main, $\mathrm{A} \& \mathrm{HCl}$ has also been used for bibliometric studies, such as on the international presence of studies on Catalan literature (Ardanuy et al. 2010), arts and humanities literatures in a country such as Turki (Al et al. 2006), and Spain (DortaGonzález and Ramírez-Sánchez 2014). The mapping on the basis of aggregated citations for journals in A\&HCl (Leydesdorff et al. 2011) and citation analysis studies in the humanities (Ardanu 2013) are also reported. 
The number of published literature is an important measure of the development of a research discipline. Art exhibit review is reviews of gallery or museum showings of artworks in A\&HCl. Whether art exhibit review can be recognized as an authoritative resource in arts and humanities, its significant growth in $\mathrm{A} \& \mathrm{HCl}$ has obtained more attention. In this study, art exhibit reviews in A\&HCl from 1994 to 2013 were considered to be analyzed. Characteristics of art exhibit reviews including languages, publication output, authors, Web of Science categories, and journals publishing the reviews were investigated.

\section{METHODOLOGY}

The information of documents used in this study was based on the $A \& \mathrm{HCl}$ of the Thomson Reuters' Web of Science Core Collection (updated on 11 December 2014). Using the search tools in Web of Science Core Collection, a total of 36 document types from 1994 to 2013 were found in $A \& \mathrm{HCl}$, including 52,580 art exhibit reviews. All art exhibit reviews were downloaded into spreadsheet software, and additional coding was manually performed using Excel 2007, as described in Li and Ho (2008).

Only 41,623 art exhibit reviews from the 1,744 journals in $\mathrm{A} \& \mathrm{HCl}$ in 2014 were selected. In the $A \& H C l$, the corresponding author is designated as the "reprint author"; in this study the term "corresponding author" is used. In a single author art exhibit review where authorship is unspecified, the single author is both the first author and corresponding author (Lin and Ho 2015). Similarly, in a single institutional art exhibit review, the institution is classified as the first author institution and the corresponding author institution (Lin and HO 2015).

\section{RESULTS AND DISCUSSION}

\section{Languages}

There are 41,623 art exhibit reviews written in 20 languages. English, as the most popular language, comprises 74 percent of the total art exhibit reviews and is followed by French (9,767 art exhibit reviews; 23 percent of 41,623 art exhibit reviews), and Spanish (535; 1.3 percent). Other languages that are less used are as follows: Italian (216 reviews), German (146), Swedish (24), and Russian (12). Still some other languages least used in art exhibit reviews are Chinese (5), Czech (5), Dutch (3), Catalan (2), Japanese (2), Norwegian (2), Rumanian (2), and one for Croatian, Estonian, Finnish, Lithuanian, Portuguese, and Slovak, respectively. The percentage of English used in art exhibit reviews in $\mathrm{A} \& \mathrm{HCl}$ was found to be lower than the percentage of articles indexed in SCIE (Lin et al. 2011; Suk et al., 2011; Han and Ho, 2011; Tanaka and Ho, 2011). Furthermore, 9,767 art exhibit reviews were written in French published in 37 journals, for example Connaissance des Arts (7,262 art exhibit reviews; 74 percent by French art exhibit reviews), Historia (1,054; 11 percent), Revue des Musees de France-Revue du Louvre (593; 6.1 percent), and Quinzaine Litteraire (496; 5.1 percent).

\section{Publication Output}

From 1994 through 2013, the annual number of art exhibit reviews in A\&HCl fluctuated from 1,467 in 1996 to 2,843 in 2009 (Table 1). For 34,454 (83 percent of 41,623 reviews) 
art exhibit reviews, the average number of authors was found to be constant in the studied 20 years. Eighty-two percent of all 41,623 art exhibit reviews were written by single author, 0.49 percent was written by two authors, 0.041 percent by three authors, 0.012 percent four authors, 0.014 percent five authors, 0.0024 percent seven authors, and 17 percent was anonymous. Such high percentage of single-author articles in art exhibit reviews probably indicated authors' independent view of art.

Table 1: Characteristics of Art Exhibit Reviews in A\&HCl, 1994-2013.

\begin{tabular}{ccccccccc}
\hline Year & $\boldsymbol{T P}$ & $\boldsymbol{T} \boldsymbol{P}^{*}$ & $\boldsymbol{A U ^ { * }}$ & $\boldsymbol{A U ^ { * } / T P ^ { * }}$ & $\boldsymbol{N R}$ & $\boldsymbol{N R} / \boldsymbol{T P}$ & $\boldsymbol{P G}$ & $\boldsymbol{P G / T P}$ \\
\hline 1994 & 1,540 & 1,378 & 1,388 & 1.0 & 2,458 & 1.6 & 2,308 & 1.5 \\
1995 & 1,630 & 1,405 & 1,407 & 1.0 & 2,686 & 1.6 & 2,675 & 1.6 \\
1996 & 1,467 & 1,327 & 1,331 & 1.0 & 2,812 & 1.9 & 2,291 & 1.6 \\
1997 & 1,525 & 1,288 & 1,302 & 1.0 & 3,370 & 2.2 & 2,378 & 1.6 \\
1998 & 2,028 & 1,553 & 1,561 & 1.0 & 3,912 & 1.9 & 2,991 & 1.5 \\
1999 & 2,076 & 1,676 & 1,685 & 1.0 & 4,185 & 2.0 & 8,744 & 4.2 \\
2000 & 2,216 & 1,662 & 1,670 & 1.0 & 4,361 & 2.0 & 3,636 & 1.6 \\
2001 & 2,320 & 1,681 & 1,688 & 1.0 & 4,407 & 1.9 & 3,500 & 1.5 \\
2002 & 1,953 & 1,590 & 1,596 & 1.0 & 3,896 & 2.0 & 3,357 & 1.7 \\
2003 & 1,538 & 1,512 & 1,515 & 1.0 & 3,532 & 2.3 & 2,619 & 1.7 \\
2004 & 1,629 & 1,496 & 1,503 & 1.0 & 3,789 & 2.3 & 2,936 & 1.8 \\
2005 & 2,343 & 1,939 & 1,950 & 1.0 & 5,421 & 2.3 & 3,964 & 1.7 \\
2006 & 2,718 & 2,159 & 2,172 & 1.0 & 6,686 & 2.5 & 4,901 & 1.8 \\
2007 & 2,623 & 2,206 & 2,222 & 1.0 & 6,434 & 2.5 & 4,929 & 1.9 \\
2008 & 2,818 & 2,165 & 2,216 & 1.0 & 6,140 & 2.2 & 4,724 & 1.7 \\
2009 & 2,843 & 2,253 & 2,284 & 1.0 & 4,830 & 1.7 & 4,618 & 1.6 \\
2010 & 2,475 & 1,931 & 1,943 & 1.0 & 3,801 & 1.5 & 3,905 & 1.6 \\
2011 & 2,183 & 1,860 & 1,880 & 1.0 & 3,751 & 1.7 & 3,799 & 1.7 \\
2012 & 1,862 & 1,711 & 1,736 & 1.0 & 3,650 & 2.0 & 3,216 & 1.7 \\
2013 & 1,836 & 1,662 & 1,686 & 1.0 & 3,320 & 1.8 & 3,201 & 1.7 \\
\hline Total & 41,623 & 34,454 & 34,735 & & 83,441 & & 74,692 & \\
\hline Average & & & & 1.0 & & 2.0 & & 1.8 \\
\hline
\end{tabular}

$T P$ : total number of art exhibit reviews; $A U$ : number of authors; NR: number of references cited; $P G$ : total page count; *: not including anonymous art exhibit reviews

A similar result was also reported in dance field in $\mathrm{A} \& \mathrm{HCl}$ (Ho and Ho 2015). The average art exhibit review length fluctuated slightly, showing a maximum of 4.2 pages in 1999 and a minimum of 1.5 pages in 1994, 1995, and 1996 respectively, with an overall average length of 1.8 pages. The numbers of reference cited also fluctuated from a minimum of 1.5 references per paper in 2010 to a maximum of 2.5 in 1994 and 1995 respectively; the overall average was 2.0 references per paper. The results of low values of references per paper were very different from research in Science Citation Index Expanded (Xie et al. 2008) and Social Science Citation Index (Huang and Ho 2011). Such low value of average cited reference can be found in dance field in Arts \& Humanities Citation Index (Ho and Ho 2015). In addition, the average number of authors and references cited were found clearly increased in last two decades. 


\section{Authors}

The results of author analysis identified those researchers who have made significant contributions in review of artworks. There were 7,169 (17 percent of 41,623 art exhibit reviews) reviews without author information and identified as anonymous in Web of Science. In general, papers as anonymous were published by journals' editorials. Among the 6,008 authors contributing to 34,454 art exhibit reviews with author information in $\mathrm{A} \& \mathrm{HCl}, 3,559$ authors (59 percent of 6,008 authors) published only one art exhibit review, 807 authors ( 13 percent) published two, and 364 authors (6.1 percent) published three. Fifty ( 0.83 percent) authors published 100 or more the art exhibit reviews. Table 2 lists the top 20 authors with three indicators of total number of art exhibit reviews, first author art exhibit reviews, and corresponding author art exhibit reviews.

Table 2: Top 20 Most Productive Authors of Art Exhibit Reviews during 1994-2013

\begin{tabular}{|c|c|c|c|c|}
\hline Author & Rank (TP) & Rank (FP) & Rank $(R P)$ & Rank (SP) \\
\hline Ledes, A.E. & 1 (439) & 1 (439) & 1 (439) & 1 (439) \\
\hline Leffingwell, E. & 2 (389) & 2 (389) & 2 (389) & 2 (389) \\
\hline Picard, D. & $3(375)$ & $3(375)$ & $3(375)$ & $3(375)$ \\
\hline Wei, L. & $4(361)$ & $4(361)$ & $4(360)$ & $4(360)$ \\
\hline Kramer, M. & $5(325)$ & $5(325)$ & $5(325)$ & $5(325)$ \\
\hline Koplos, J. & $6(310)$ & $6(310)$ & $6(310)$ & $6(310)$ \\
\hline Heartney, E. & $7(301)$ & $7(301)$ & $7(301)$ & $7(301)$ \\
\hline Raillard, G. & $8(281)$ & $8(280)$ & $8(276)$ & $8(276)$ \\
\hline Goodman, J. & $9(270)$ & $9(270)$ & $9(270)$ & $9(270)$ \\
\hline Princenthal, N. & $10(262)$ & $10(262)$ & $10(262)$ & $10(262)$ \\
\hline Pollack, B. & $11(253)$ & $11(253)$ & $11(253)$ & $11(253)$ \\
\hline Landi, A. & $12(229)$ & $12(229)$ & $12(229)$ & $12(229)$ \\
\hline Blin, S. & $13(205)$ & $13(205)$ & $13(205)$ & $13(205)$ \\
\hline Ebony, D. & $14(202)$ & 14 (199) & $15(198)$ & $15(198)$ \\
\hline Duncan, M. & 15 (199) & 14 (199) & 14 (199) & 14 (199) \\
\hline MacAdam, B.A. & $16(190)$ & 16 (189) & $16(189)$ & $16(189)$ \\
\hline Sagnier, C. & 17 (179) & 17 (179) & $17(179)$ & 17 (179) \\
\hline Weil, R. & $18(178)$ & $18(178)$ & $18(178)$ & $18(178)$ \\
\hline Baker, $\mathrm{K}$. & $19(173)$ & $19(173)$ & 19 (173) & $19(173)$ \\
\hline Feaver, W. & 20 (167) & 20 (167) & 20 (167) & 20 (167) \\
\hline
\end{tabular}

$T P$ : total number of art exhibit reviews; $F P$ : first author art exhibit reviews, $R P$ : corresponding author art exhibit reviews; SP: single author art exhibit reviews.

In the science discipline, it is generally accepted that the most important authorship positions are the first and the last, who very often is the corresponding author (Costas and Bordons 2011). A total of 34,454 and 34,241 art exhibit reviews had author and corresponding author information respectively, including 34,223 single author art exhibit reviews (99 percent of 34,454 art exhibit reviews with author information). Single author was the typical style for the art exhibit reviews. The single authorship was also prevalent in 
arts and humanities journal articles written by authors affiliated with Turkish institutions and indexed in A\&HCl (Al et al. 2006). However, 'techno.seduction' an exhibition of multimedia installation work by forty artists' source was published by seven authors. The top three authors published only single author art exhibit reviews.

A.E. Ledes who was the editor of Magazine Antiques, published the most art exhibit reviews (439 reviews), as single author, which all were in the same journal i.e. Magazine Antiques. Ledes also published 64 news items, 60 articles, 60 editorial materials, eight notes, four book reviews, one biographical-item, and one reprint in Magazine Antiques from 1994 to 2013. Only one editorial material of 637 publications was published by two authors, others were single author publications. Allison Eckardt Ledes (1954-2008) (Garrett 2008) joined Magazine Antiques in 1975 and focused on modern painting and sculpture in college; she was self-taught in the decorative arts but quickly became an authority in the field (Cash and Ebony 2008).

E. Leffingwell was ranked $2^{\text {nd }}$ and published 388 art exhibit reviews in Art in America and one in Artnews. Edward Leffingwell (1941-2014) was curator, writer and former Brazil correspondent for Art in America (Fazzare 2014). D. Picard ranked $3^{\text {rd }}$, published 375 art exhibit reviews from 1994 to 2003 by French in Connaissance des Arts only. Denis Picard is the former editor of the magazine Connaissance des Arts.

Similarly, the editor of Dancing Times published the most papers in the dance field in $\mathrm{A} \& \mathrm{HCl}$ (Ho and Ho, 2015). In total, 34,223 reviews (99 percent of 34,454 art exhibit reviews with author information in Web of Science) were published by single author, 202 reviews by two authors, 17 reviews by three authors, five reviews by four authors, six reviews by five authors, and one reviews by seven authors.

\section{Web of Science Categories and Journals}

There were 1,744 journals listed in 28 subject categories in A\&HCl. In total, 41,623 art exhibit reviews were published in 251 journals in 26 categories (Table 3). Only two categories i.e. history and philosophy of science and Slavic literature had no art exhibit reviews in $A \& \mathrm{HCl}$. The leading Web of Science categories were art with 35,252 art exhibit reviews ( 85 percent of 41,623 art exhibit reviews with Web of Science category in A\&HCl), followed distantly by history with 2,119 (5.1 percent) art exhibit reviews, multidisciplinary humanities $(1,384 ; 3.3$ percent), and architecture $(1,110 ; 2.7$ percent). The art category had also the highest average of art exhibit reviews with 425 art exhibit reviews per journal. The category of architecture $(T P / N J=23)$ was higher than the category of multidisciplinary humanities $(T P / N J=10)$.

However, there were 48 journals in the category of architecture while 139 journals were in the category of multidisciplinary humanities. Figure 1 shows that art exhibit reviews published in the Web of Science's category of art were much higher than any other categories. It is interesting that art exhibit reviews in the history category in earlier decade were much higher than in later decade. The number of publications in multidisciplinary humanities, history, and architecture were found to be similar in recent years. In recent years, the number of publications in categories such as literature, literary reviews, archaeology, romance literature, and theater were getting less even to zero.

There were 41,623 art exhibit reviews in 251 different $A \& H C l$ journals. Seventy-six percent of 41,623 art exhibit reviews were published in only five specific journals in category of art: Art in America (8,199; 20 percent of 41,623 art exhibit reviews), Artnews (7,954; 19 
percent), Connaissance des Arts (7,326; 18 percent), Artforum International (5,400; 13 percent), and Burlington Magazine (2,528; 6.1 percent). The statistical results might help researchers select journals when publishing their art exhibit reviews. The most frequently cited art exhibit review was 'Suffragettes, soldiers, and servants': Behind the scenes of the Hampton Court Palace community 1750-1950 (Parker 2005) published in History Today listed in the category of history with 80 citations from 2005 to 2010.

Table 3: A\&HIC Categories in the Web of Science Publishing Art Exhibit Reviews

\begin{tabular}{|c|c|c|c|c|}
\hline Web of Science Category of A\&HCI & $T P$ & $\%$ & NJ & $T P / N J$ \\
\hline Art & 35,252 & 85 & 83 & 425 \\
\hline History & 2,119 & 5.1 & 288 & 7.4 \\
\hline Multidisciplinary humanities & 1,384 & 3.3 & 139 & 10 \\
\hline Architecture & 1,110 & 2.7 & 48 & 23 \\
\hline Literature & 532 & 1.3 & 132 & 4.0 \\
\hline Literary reviews & 398 & 1.0 & 55 & 7.2 \\
\hline Archaeology & 199 & 0.48 & 91 & 2.2 \\
\hline Romance literature & 141 & 0.34 & 69 & 2.0 \\
\hline Theater & 138 & 0.33 & 32 & 4.3 \\
\hline Film, radio, television & 93 & 0.22 & 33 & 2.8 \\
\hline Folklore & 79 & 0.19 & 19 & 4.2 \\
\hline Dance & 60 & 0.14 & 9 & 6.7 \\
\hline Asian studies & 52 & 0.12 & 59 & 0.88 \\
\hline Music & 36 & 0.086 & 79 & 0.46 \\
\hline Medieval and renaissance studies & 34 & 0.082 & 45 & 0.76 \\
\hline British Isles literature & 17 & 0.041 & 23 & 0.74 \\
\hline Poetry & 13 & 0.031 & 16 & 0.81 \\
\hline African, Australian, Canadian literature & 7 & 0.017 & 6 & 1.2 \\
\hline Religion & 7 & 0.017 & 137 & 0.051 \\
\hline American literature & 4 & 0.010 & 20 & 0.20 \\
\hline Cultural studies & 3 & 0.0072 & 38 & 0.079 \\
\hline Philosophy & 3 & 0.0072 & 177 & 0.017 \\
\hline Language and linguistics & 3 & 0.0072 & 190 & 0.016 \\
\hline German, Dutch, Scandinavian literature & 2 & 0.0048 & 24 & 0.083 \\
\hline Literary theory and criticism & 1 & 0.0024 & 22 & 0.045 \\
\hline Classics & 1 & 0.0024 & 47 & 0.021 \\
\hline
\end{tabular}

TP: total number of art exhibit reviews; $N J$ : number of journals in a category. 


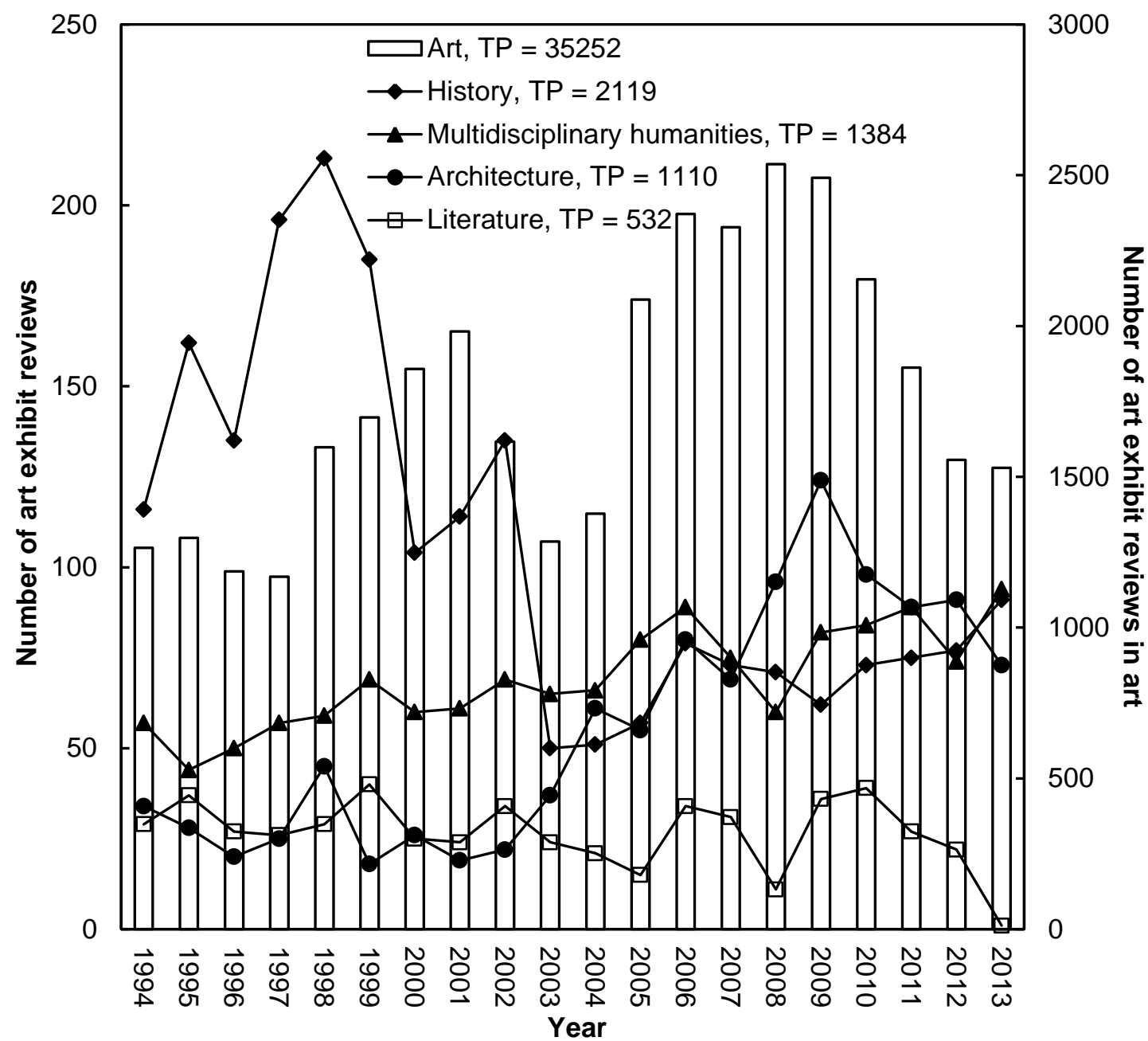

Figure 1: Publications of the Five Most Productive Web of Science Subject Categories, 1994-2013.

\section{Words in Art Exhibit Reviews' Title}

The technique of statistical analysis of keywords and title-words might be aimed at discovering directions of science (Garfield 1990). Distribution of words in article title has been studied for research trends and focus (Xie et al. 2008). The prepositions, articles, and conjunctions in title were excluded from the statistical analysis. The top 20 most frequently used single words in title were listed in Table 4. "Art" was the most frequently used single words in title during the period 1994-2013, followed distantly by "artists", "new", "collection", and "American". Some title-word related to name of people in art field such as "John", "Robert", "David", and "Richard" were also found in top 20 used words in title of art exhibit reviews. John might be for example John Baldessari, John Singer, John Currin, John Chamberlain, John Soane, and John Armleder. Robert might be for example Robert Rauschenberg, Robert Morris, Robert Ryman, Robert Smithson, and Robert Gober. David might be for example David Hockney, David Smith, David Hammons, David Weiss, David Mach, and David Friedrich. Richard might be for example Richard Serra, Richard Artschwager, Richard Long, Richard Tuttle, Richard Prince, and Richard Diebenkorn. It is clear from Table 4 that "world", "modern", "contemporary", "museum", "artists", "life", and "architecture" had a notable increasing trend from period 1994-1998 to 2009-2013. By contrast, the words "American", "drawings", and "years" in title showed a clear decrease during the study period. In addition, discussion of artists with names as "John", "Robert", "David", and "Richard" were also getting less in art exhibit reviews. 
Wang, W.M. \& Ho, Y.S.

Table 4: Top 20 Most frequently Used Single Word Art Exhibit Reviews' Title

\begin{tabular}{|c|c|c|c|c|c|c|}
\hline Words in title & $T P$ & 94-13 R (\%) & 94-98 R (\%) & 99-03 R (\%) & 04-08 R (\%) & $09-13 R(\%)$ \\
\hline art & 2,090 & $1(5.0)$ & 1 (5.1) & $1(6.3)$ & $1(4.8)$ & $2(4.0)$ \\
\hline artists & 913 & $2(2.2)$ & $14(0.77)$ & $13(1.0)$ & $32(0.56)$ & $1(6.1)$ \\
\hline new & 602 & $3(1.4)$ & $10(0.93)$ & $4(1.6)$ & $2(1.8)$ & $3(1.3)$ \\
\hline collection & 494 & $4(1.2)$ & $5(1.1)$ & $7(1.3)$ & $3(1.3)$ & $7(0.95)$ \\
\hline American & 489 & $5(1.2)$ & $2(1.4)$ & $2(1.7)$ & $7(1.0)$ & $13(0.73)$ \\
\hline John & 444 & $6(1.1)$ & $4(1.2)$ & $10(1.2)$ & $6(1.0)$ & $8(0.88)$ \\
\hline Robert & 431 & $7(1.0)$ & $3(1.4)$ & $11(1.1)$ & $7(1.0)$ & $11(0.78)$ \\
\hline painting & 430 & $8(1.0)$ & $8(1.0)$ & $6(1.4)$ & $9(1.0)$ & $9(0.80)$ \\
\hline David & 424 & $9(1.0)$ & $6(1.1)$ & $9(1.3)$ & $5(1.0)$ & $15(0.71)$ \\
\hline century & 416 & $10(1.0)$ & $13(0.79)$ & $5(1.6)$ & $10(0.88)$ & $12(0.77)$ \\
\hline museum & 416 & $10(1.0)$ & $26(0.63)$ & $3(1.6)$ & $19(0.73)$ & $6(1.0)$ \\
\hline drawings & 374 & $12(0.90)$ & $9(1.0)$ & $8(1.3)$ & $18(0.73)$ & $20(0.68)$ \\
\hline paintings & 362 & $13(0.87)$ & $23(0.70)$ & $12(1.0)$ & $4(1.1)$ & $25(0.63)$ \\
\hline Richard & 339 & $14(0.81)$ & $7(1.0)$ & $21(0.75)$ & $14(0.82)$ & $19(0.70)$ \\
\hline modern & 324 & $15(0.78)$ & $33(0.54)$ & $19(0.77)$ & $19(0.73)$ & $5(1.0)$ \\
\hline world & 324 & $15(0.78)$ & $40(0.50)$ & $41(0.58)$ & $11(0.87)$ & $4(1.1)$ \\
\hline architecture & 319 & $17(0.77)$ & $17(0.76)$ & $35(0.63)$ & $12(0.85)$ & $9(0.80)$ \\
\hline life & 299 & $18(0.72)$ & $25(0.65)$ & $37(0.62)$ & $13(0.83)$ & $13(0.73)$ \\
\hline years & 294 & $19(0.71)$ & $11(0.85)$ & $24(0.73)$ & $22(0.64)$ & $22(0.64)$ \\
\hline contemporary & 293 & $20(0.70)$ & $40(0.50)$ & $21(0.75)$ & $15(0.79)$ & $15(0.71)$ \\
\hline
\end{tabular}

TP: publications in the study period; $R$ (\%): rank (percentage of publications containing this titleword).

\section{CONCLUSION}

This study has shown that for art exhibit reviews indexed in A\&HCl, the dominant language was English but its percentage was lower than most research articles in SCIE. Single author was the most popular authorship. Authors preferred to publish their art exhibit reviews in the same journal. The editor of Magazine Antiques, A.E. Ledes published the most art exhibit reviews followed by the editors of Art in America and Connaissance des Arts. Art exhibit reviews were published in 26 of 28 subject categories in $\mathrm{A} \& \mathrm{HCl}$. Art was the leading subject category publishing 85 percent of art exhibit reviews. Seventy-six percent of art exhibit reviews were published in five journals. Artists, art, new, world, modern, museum, and collection were the popular words used in art exhibit reviews' title. Art exhibit reviews were originally analyzed, providing certain unique and undiscovered characteristics of the $\mathrm{A} \& \mathrm{HCl}$. 


\section{ACKNOWLEDGEMENT}

This research received no specific grant from any funding agency in the public, commercial, or not-for profit sectors.

\section{REFERENCES}

Agudelo, D., Breton-Lopez, J. and Buela-Casal, G. 2003. Bibliometric analisis of the reviews of Clinical Psychology published in Spanish. Psicothema, Vol. 15, no. 4:507-516.

Al, U., Şahiner, M. and Tonta, Y. 2006. Arts and humanities literature: Bibliometric characteristics of contributions by Turkish authors. Journal of the American Society for Information Science and Technology, Vol. 57, no. 8:1011-1022.

Ardanuy, J. 2013. Sixty years of citation analysis studies in the humanities (1951-2010). Journal of the American Society for Information Science and Technology, Vol. 64, no. 8:1751-1755.

Ardanuy, J., Quintana, L. and Urbano, C. 2010. International presence of studies on Catalan literature in the Arts \& Humanities Citation Index. Revista Española de Documentación Científica, Vol. 33, no. 2:298-309.

Cash, S. and Ebony, D. 2008. Allison Eckardt Ledes - Obituary. Art in America, Vol. 96, no. 3:198

Chiu, W.T. and Ho, Y.S. 2007. Bibliometric analysis of tsunami research. Scientometrics, Vol. 73, no. 1:3-17.

Costas, R. and Bordons, M. 2011. Do age and professional rank influence the order of authorship in scientific publications? Some evidence from a micro-level perspective. Scientometrics, Vol. 88, no. 1:145-161.

Dorta-González, P. and Ramírez-Sánchez, M. 2014. Production and impact of the Spanish research institutions in Arts \& Humanities Citation Index (2003-2012). Arbor-Ciencia Pensamiento y Cultura, Vol. 190, no. 770: Article Number: a191.

Fazzare, E. 2014. Edward Leffingwell, 1941-2014. Art in America. News Aug. 13, http://www.artinamericamagazine.com/news-features/news/edward-leffingwell-19412014/.

Garfield, E. 1990. KeyWords Plus: ISI's breakthrough retrieval method. Part 1. Expanding your searching power on Current Contents on Diskette. Current Contents, Vol. 32, 5-9.

Garrett, W. 2008. Antiques: Allison Eckardt Ledes 1954-2008. Magazine Antiques, Vol. 173, no. 2:47

Han, J.S. and Ho, Y.S. 2011. Global trends and performances of acupuncture research. Neuroscience and Biobehavioral Reviews, Vol. 35, no. 3:680-687.

Ho, Y.S. 2013. The top-cited research works in the Science Citation Index Expanded. Scientometrics, Vol. 94, no. 3:1297-1312.

Ho, Y.S. 2014. Classic articles on social work field in Social Science Citation Index: A bibliometric analysis. Scientometrics, Vol. 98, no. 1:137-155.

Ho, Y.S. and Kahn, M. 2014. A bibliometric study of highly cited reviews in the Science Citation Index Expanded ${ }^{\mathrm{TM}}$. Journal of the Association for Information Science and Technology, Vol. 65, no. 2:372-385.

Ho, H.C. and Ho, Y.S. 2015. Publications in dance field in Arts \& Humanities Citation Index: A bibliometric analysis. Scientometrics, Vol. 105, no. 2:1031-1040.

Huang, C.Y. and Ho, Y.S. 2011. Historical research on corporate governance: A bibliometric analysis. African Journal of Business Management, Vol. 5, no. 2:276-284.

Ingwersen, P., Larsen, B., Garcia-Zorita, J.C., Serrano-Lopez, A.E. and Sanz-Casado, E. 2014. Influence of proceedings papers on citation impact in seven sub-fields of sustainable 
energy research 2005-2011. Scientometrics, Vol. 101, no. 2:1273-1292.

Justiss, L. K. 1993. A bibliometric study of Texas law reviews. Law Library Journal, Vol. 85, no. 2:407-408.

Leydesdorff, L., Hammarfelt, B. and Salah, A. 2011. The structure of the Arts \& Humanities Citation Index: A mapping on the basis of aggregated citations among 1,157 journals. Journal of the American Society for Information Science and Technology, Vol. 62, no. 12:2414-2426.

Li, Z. and Ho, Y.S. 2008. Use of citation per publication as an indicator to evaluate contingent valuation research. Scientometrics, Vol. 75, no. 1:97-110.

Lin, C.L. and Ho, Y.S. 2015. A bibliometric analysis of publications on pluripotent stem cell research. Cell Journal, Vol. 17, no. 1:59-70.

Lin, H.W., Yu, T.C. and Ho, Y.S. 2011. A systemic review of the human papillomavirus studies: Global publication comparison and research trend analyses from 1993 to 2008. European Journal of Gynaecological Oncology, Vol. 32, no. 2:133-140.

Manriquez, J., Andino-Navarrete, R., Cataldo-Cerda, K. and Harz-Fresno, I. 2015. Bibliometric characteristics of systematic reviews in dermatology: A cross-sectional study through Web of Science and Scopus. Dermatologica Sinica, Vol. 33, no. 3:154-156.

Parker, S. 2005. 'Suffragettes, soldiers, and servants': Behind the scenes of the Hampton Court Palace community 1750-1950. History Today, Vol. 55, no. 4:2-3.

Sigogneau, A. 2000. An analysis of document types published in journals related to physics: Proceeding papers recorded in the Science Citation Index database. Scientometrics, Vol. 47, no. 3:589-604.

Suk, F.M., Lien, G.S., Yu, T.C. and Ho, Y.S. 2011. Global trends in Helicobacter pylori research from 1991 to 2008 analyzed with the Science Citation Index Expanded. European Journal of Gastroenterology \& Hepatology, Vol. 23, no. 4:295-301.

Tanaka, H. and Ho, Y.S. 2011. Global trends and performances of desalination research. Desalination and Water Treatment, Vol. 25, no. 1-3:1-12.

Xie, S.D., Zhang, J. and Ho, Y.S. 2008. Assessment of world aerosol research trends by bibliometric analysis. Scientometrics, Vol. 77, no. 1:113-130.

Zhang, L. and Glanzel, W. 2012. Proceeding papers in journals versus the "regular" journal publications. Journal of Informetrics, Vol. 6, no. 1:88-96. 